\title{
SOME PROPERTIES OF DUMYAT GOVERNORATE SOILS AS AFFECTED BY THE DISTANCE FROM THE MEDITERRANEAN SEA
}

EL-Agrodi, M. W. M. ${ }^{1}$; G. Labeeb ${ }^{1}$; Fatma A. Ghaly ${ }^{2}$ and A. S. Abd EL-Hameed ${ }^{2}$

1. Soils Dept . Fac. Of Agri. Mansoura univ

2. Soils Dept .Damietta Fac. Of Agri. Mansoura Univ

\begin{abstract}
To evaluate the effect of the Mediterranean sea on some soil chemical and physical properties of Dumyat Governorate, nineteen soil profiles ( $1 \mathrm{Km}$ apart )were studied. Soil samples were taken from each profile at four depths, (0-30, 30-60, 60-90 and $90-120 \mathrm{~cm})$. The obtained results can be summarized in:

- Very little differences were found between layers of each profile (1-3) in coarse sand . In the fourth and fifth profiles the highest values (24.72 and $18.13 \%$ ) of coarse sand were observed in layer c $(60-90 \mathrm{~cm})$. Coarse sand of profiles 6 to 19 was very little, where it did not exceeds than $2.65 \%$ (means of layers of each profiles).

- Fine sand is the predominant component of soil profiles from 1 to 5 . The positive correlation were found between fine sand in each layer and the distance from the sea ( profile 6-19 data), where the correlation coefficient are $0.70,0.63,0.63$, and 0.41 .

- Silt content was increased with increasing the distance up to $22.65 \%$ in profile 5 . Silt content of profiles $6-19$ are ranged from $20.61 \%$ to $48.42 \%$ where the highest value for profile 6 . The highest value of clay percentage $(86.86 \%)$ was found in profile 7 at the depth of $60-90 \mathrm{~cm}$.

- Soil organic matter content tend to be high in profiles 6-19, where it is amounted by $0.36 \%$ ( layers mean of profile 19 ) at the farthest point from the sea and 0.46 $\%$ at the nearest point from the sea ( layers mean of profile 6 ). In most cases of profiles 6-19 soil organic matter contents were higher in surface layer.

- Total carbonates of the heavy textured soils (from $6-19$ ) lie in the normal range of total carbonate of delta soil (1.42\% layers mean of profile 11 and 4.425 means of profile 14). In most cases the second layers have the highest amount of total carbonate compared with the other layers.

- The obtained results of saturation percentage of soils nearest the sea are high (33.5 to $40.2 \%$ ) compared with the other soil lie in the same textured class. This due to the dominance of very fine sand and silt in soil particles and to the higher soil salinity level.

- Soil pH of layer A and B was increased with increasing the distance from the sea in the two groups of profiles. Where the $\mathrm{pH}$ of layers $\mathrm{C}$ and $\mathrm{D}$ was decrease with increasing distance in the first group of profiles (1-5) then increased with increasing distance in the second group (profile 6-19).

- The relation between cation exchange capacity of the studied soils and thier clay content was explained by the following equation $y=0.9984 x+8.7467$.

- No constant trend was found in exchangeable sodium percentage with increasing the distance from the sea up to $5 \mathrm{~km}$ in $A, B$, and $C$ layer where in layer $D$ the exchangeable sodium percentage was increased with increasing the distance up to $4 \mathrm{~km}$ then decreased. This decrease may be due to presence of drain beside.
\end{abstract}




\section{INTRODUCTION}

The coastal soils of Dumyat Governorate is one of the distinguished fluvial land forms. The area consists of deposition of sediments particles due to the reduction of the river Nile velocity as the flow enters the body of the Mediterranean Sea water. Sediment deposits in the delta are usually fine sand, silt and clay depending on controlling variables.

Nile sediments particles contains a lot of expanding clay minerals such as montmorillonite (62.68\% to $85.04 \%$ ) (Abd-Allah et al., 2009)

This study deals with the effect of the sea on these fluvial land properties such as particle size distribution, cation exchange capacity, organic matter, total carbonate, $\mathrm{pH}$, saturation percentage and exchangeable sodium percentage of Dumyat Governorate and how far the effect of the distance from the sea on these soil properties.

\section{MATERIALS AND METHODS}

To evaluate the effect of the Mediterranean sea on some soil chemical and physical properties of Dumyat Governorate, nineteen soil profiles were done in nineteen site of Dumyat governorate ( Fig. 1), which were studied to achieve the target of this research. The studied area exists in between latitude $30^{\circ} ; 32 \mathrm{~N}$ and $31^{\circ} ; 15 \mathrm{~N}$ and between longitude $31^{\circ} ; 45 \mathrm{E}$ and $31^{\circ} ; 30 \mathrm{E}$.

The first profile is far $1.0 \mathrm{Km}$ from the Mediterranean Sea and the distance between each adjacent two profiles was $1.0 \mathrm{Km}$ intervals. Soil samples were taken from each profile at four depths, $(0-30,30-60,60-90$ and 90-120 cm)

Soil samples were taken at March 2009 then air dried, ground, and sieved through a $2 \mathrm{~mm}$ sieve and preserved for further analysis. The selected soil analysis were particles size distribution, soil organic matter, total carbonate, cation exchange capacity, saturation percentage, soil reaction, and exchangeable sodium percent.

- Particle size distribution was determined using the international pipette, method as described by Black (1965).

- Total carbonate percentage ( using collin's calcimeter) and organic matter content ( welkly black rapid titration method) were determined as described by Dewis and Freitas (1970).

- $\mathrm{pH}$ value of soil was determined in soil paste using Beckman $\mathrm{pH}$ meter, Exchangeable sodium, Exchangeable sodium percentage and cation exchange capacity were analyzed as described by Jakson (1967).

- correlations coefficients between parameters were estimated by Costat Program (Version 6.303, CoHort, USA, 1998-2004) 


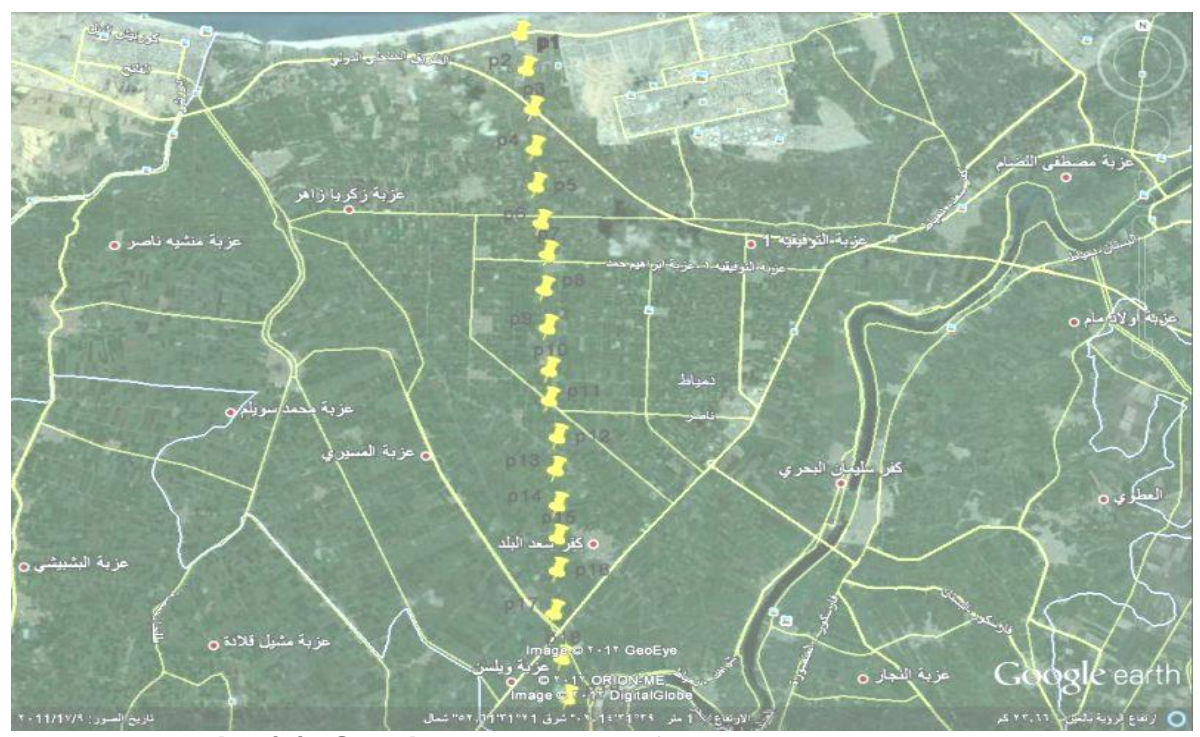

Fig. (1): Studied area map of Dumyat governorate.

\section{RESULTS AND DISCUSSION}

\section{Particle Size Distribution and soil texture.}

Data of Fig. (2) show that the coarse sand of profile 1 differed from $24.81 \%$ to $9.39 \%$. The highest value was recorded in $0.0-30 \mathrm{~cm}$ layer. The whole mean of coarse sand of that profiles $15.18 \%$. Coarse sand in second and third profiles were similar, where no much change was found (13.29 and $13.28 \%$ ) as whole mean. At the same time, very little differences were found between layers of each profile. In the fourth and fifth profiles the highest values (24.72 and $18.13 \%)$ of coarse sand were observed in layer c (60$90 \mathrm{~cm}$ ). These profiles (1-5) had no constant trend of coarse sand with depth. Coarse sand in the rest profiles (from 6 to 19) is very little, where it did not exceeds than $2.65 \%$ (profile 18 mean). In general coarse sand percentage in the soil profile was negatively and significantly correlated with the distance from the sea $(-0.634)$. On the other hand, non-significant correlation was found between soil layers depth and coarse sand (-0.118). Coarse sand percentage in profiles from 6 to 19 except number 9 decreased with soil depth. These results are in agreement with the results of Tayel et. al., (2010) who found that coarse sand percentage was higher in the surface soil then decrease downwards and attributed that to soil management. Data presented in Fig. (3) reveal that fine sand is the predominant component of soil profiles from 1 to 5 , it represents $71.85,61.45,58.64,46.48$ and $52.98 \%$ (whole mean of layer of profiles). The lower layers of profiles (1 and 2) have the highest values (79.69 and 69.6\%). In profiles 3 and 4 the highest values were found in layer of $30-60 \mathrm{~cm}$ whereas in profile 5 the highest value was found in layer of $0.0-30 \mathrm{~cm}$. A negative significant correlations between fine sand percentage in each layer and the distance from the Mediterranean Sea were found, where the correlation coefficient are $0.70,0.74,0.88$, and 0.92 . 
Coarse sand percentage $(\%)$ A
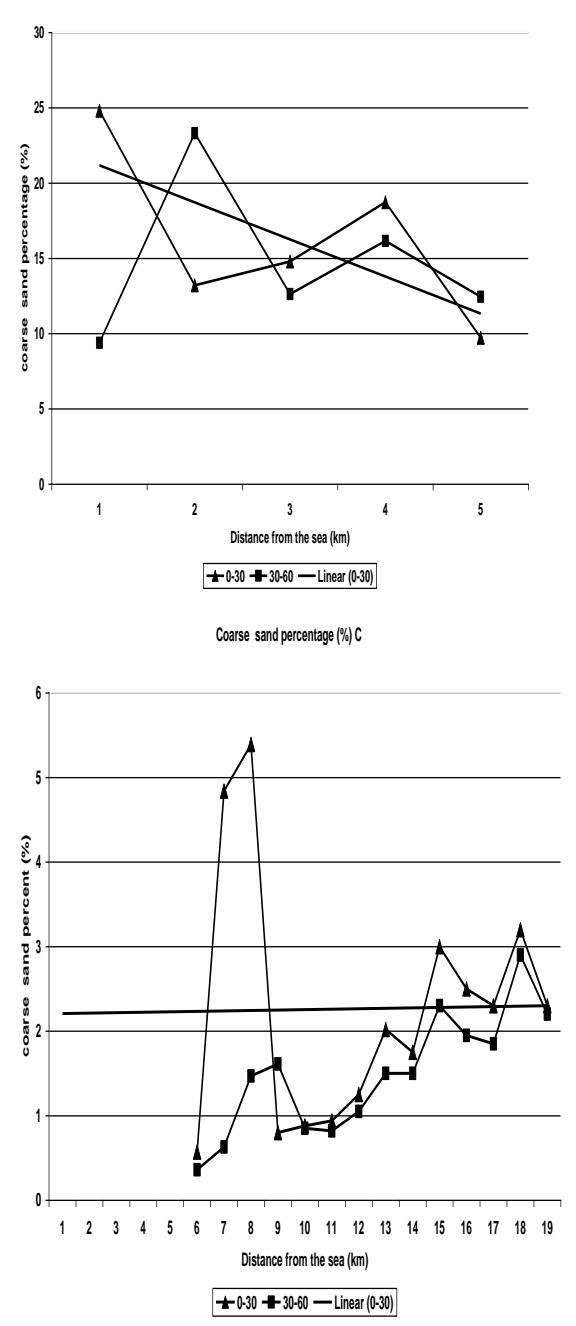

Coarse sand percentage (\%)/B

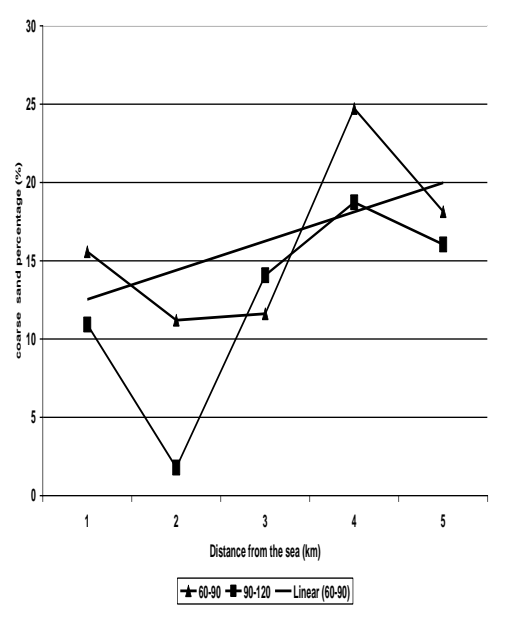

Coarse sand percentage $(\%)$ D

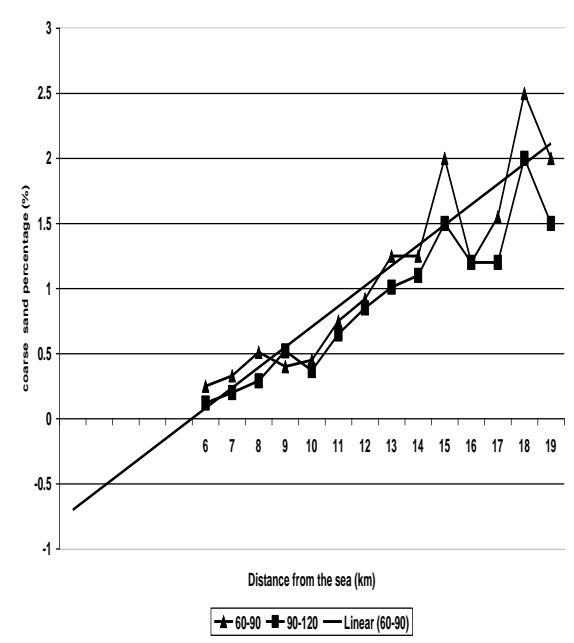

Fig. (2): Coarse sand percentage of the studied soil layer in relation to the distance from the sea. $(A=$ profiles from1 to $5-0-30$ and 30 $60 \mathrm{~cm}$ depth, $B=$ profiles from1 to $5-60-90$ and $90-120 \mathrm{~cm}$ depth, $C=$ profiles from 6 to $19-0-30$ and $30-60 \mathrm{~cm}$ depth and $D$ $=$ profiles from 6 to $19-60-90$ and $90-120 \mathrm{~cm}$ depth) 

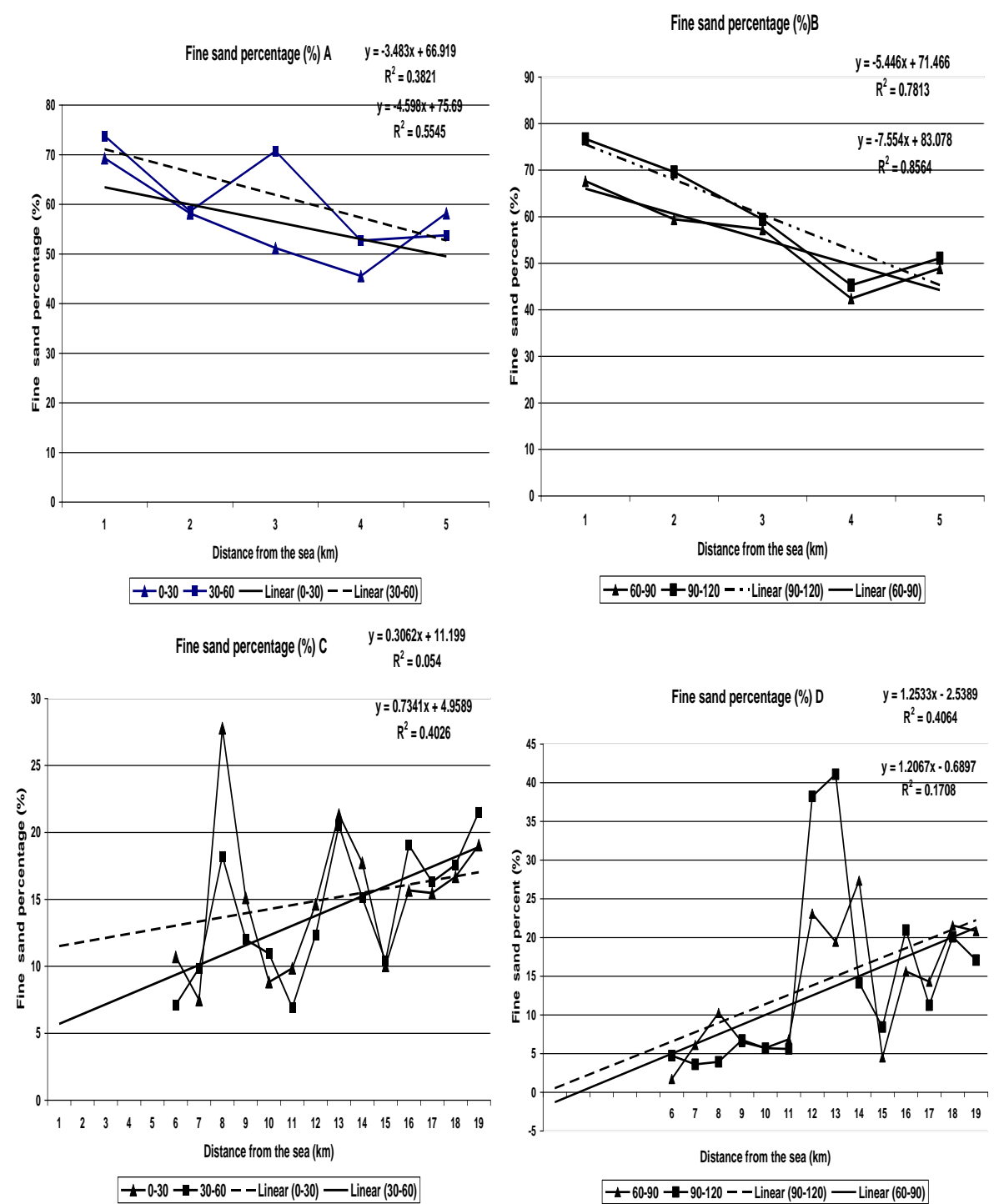

Fig. (3): Fine sand percentage of the studied soil layer in relation to the distance from the sea. ( $A=$ profiles from 1 to $5-0-30$ and $30-60$ $\mathrm{cm}$ depth, $B=$ profiles from1 to $5-60-90$ and $90-120 \mathrm{~cm}$ depth, $C=$ profiles from 6 to $19-0-30$ and $30-60 \mathrm{~cm}$ depth and $D=$ profiles from 6 to $19-60-90$ and $90-120 \mathrm{~cm}$ depth)

Fine sand of profiles 6 to 19 varied from $6.07 \%$ to $25.59 \%$. In that profiles the fine sand didn't took a constant trend with layer depth. In spite of lower values of fine sand in each layer for each profile (from 6-19) the positive correlations were found between fine sand in each layer and the distance from the sea, where the correlation coefficient are $0.70,0.63$, 
0.63 ,and 0.41 . The lowest value of fine sand $(1.78 \%)$ was found at the depth of $(60-90 \mathrm{~cm})$ in profile number 6 .

Data of Fig. (4) reveal that silt content of the profiles adjacent Mediterranean sea is very low where it represent 2.26, 3.37, 8.40 and $1.77 \%$ only (by whole mean of $3.98 \%$ ). Silt content was increased (up to $22.65 \%$ ) with increasing the distance in profile 5 . The correlation coefficient of silt with distance from the sea are $0.80,0.87,0.48$ and 0.87 for $0.0-30.0,30.0-60.0$, $60.0-90.0$ and $90.0-120.0$ layer, respectively.

Silt content of profiles $6-19$ are ranged from $20.61 \%$ to $48.42 \%$ where, the highest value for profile 6 which is the nearest one of these group to the sea, meaning that this point is the end of the Nile sediment precipitation. The correlation between silt content and the distance from the sea prove that, very little increase or decrease in that trait toward the sea in each layer, where the correlation coefficient values are $-0.29,0.15,-0.19$ and 0.08 for 0.0 -30.0, 30.0- 60.0, 60.0 -90.0 and 90.0- 120.0 layer.

No significant correlation between silt percentage and soil layers depth. The highest values of silt percentage were found in profile number 6 $(46.98$ and $57.1 \%)$ at the depths of $30-60$ and $90-120 \mathrm{~cm}$. These may be regarded to internal zone between the sea and the Nile River where the river precipitate the finest particles with lowering of its speed in the same time the sea precipitate the finest particles in the same site.

Data of Fig.(5) A and B profiles show that the mean values of clay didn't differ among the first five profiles, $(9.01,10.45,11.53,12.12$ and 10.30 $\%)$, so little migration of clay between layers was found in the second, third, fourth and fifth profile.

Non significant correlation between the clay percentage and the soil layers depth was found (Fig 5, C and D). Clay percentage in profiles 6, 7, 8, $9,10,11,15,16$ and 4 took a constant trend where it increased with increasing soil layer depth up to $90 \mathrm{~cm}$ then decreased, where the other profiles didn't took a constant trend. The highest value of clay percentage $(86.86 \%)$ was found in profile 7 at the depth of $60-90 \mathrm{~cm}$. These results may be attributed to the precipitating of finest particles (clay) from Nile water due to the difference between particles volume and time of precipitation in the connected zone between the Nile precipitates and the Mediterranean Sea output.

Data in Table (1) illustrate that soil texture in the most of profiles ranged between sandy loam and loamy sand in the first five profiles and between silty clay, clay loam and clay in the other profiles. Data in the Table (1) reveal that the internal zone between the deposits of Nile River and the Mediterranean Sea was found at the profile number 6 and 7 where soil texture was silty clay and clay. 
Table (1): Soil texture of the studied soil layer in relation to the distance from the sea.

\begin{tabular}{|c|c|c|c|c|}
\hline Profile layers & A $(\mathbf{0 . 0}-\mathbf{3 0 . 0} \mathbf{~ c m})$ & $\mathbf{B}(\mathbf{3 0 . 0 - 6 0 . 0} \mathbf{~ c m})$ & $\mathbf{C}(\mathbf{6 0 - 9 0} \mathbf{~ c m})$ & $\mathbf{D}(\mathbf{9 0 - 1 2 0} \mathbf{~ c m})$ \\
\hline Profile no, & Loamy sand & Loamy sand & Loamy sand & Sandy \\
\hline $\mathbf{1}$ & Sandy loam & Loamy sand & Sandy loam & Sandy loam \\
\hline $\mathbf{3}$ & Sandy loam & Loamy sand & Sandy loam & Sandy loam \\
\hline $\mathbf{4}$ & Sandy loam & Sandy loam & Sandy loam & Sandy loam \\
\hline $\mathbf{5}$ & Sandy loam & Sandy loam & Sandy loam & Sandy loam \\
\hline $\mathbf{6}$ & Silty clay & Silty clay & Silty clay & Silty clay \\
\hline $\mathbf{7}$ & Silty clay & Clay & Clay & Clay \\
\hline $\mathbf{8}$ & Clay & Clay & Clay & Clay \\
\hline $\mathbf{9}$ & Clay & Clay & Clay & Clay \\
\hline $\mathbf{1 0}$ & Silty clay & Clay & Clay & Clay \\
\hline $\mathbf{1 1}$ & Clay & Clay & Clay & Clay \\
\hline $\mathbf{1 2}$ & Clay & Clay & Clay & Clay loam \\
\hline $\mathbf{1 3}$ & Clay & Clay & Clay & Clay loam \\
\hline $\mathbf{1 4}$ & Clay & Clay & loam & Clay \\
\hline $\mathbf{1 5}$ & Clay & Clay & Clay & Clay \\
\hline $\mathbf{1 6}$ & Clay & Clay & Clay & Clay \\
\hline $\mathbf{1 7}$ & Clay & Clay & Clay & Silty clay \\
\hline $\mathbf{1 8}$ & Clay & Clay & Clay loam & Clay \\
\hline $\mathbf{1 9}$ & Clay & Clay & Clay & Clay \\
\hline
\end{tabular}

\section{Soil organic matter content}

Data of Fig. (6) show organic matter content of the $19^{\text {th }}$ studied profiles. In the first five profiles the organic matter content didn't exceed than $0.2 \%$. In profile 1 layers of $0.0-30.0$ and $60.0-90.0 \mathrm{~cm}$ have a slightly higher organic matter than that of the other layers. Organic matter content are higher in the higher layers of profiles 2 and 3 , where in profile 5 , constant percentage $(0.19 \%)$ of organic matter was found with the depth. In profile 4 , organic matter content increased from $0.17 \%$ to $0.19 \%$ with increasing the soil layer depth from $0.0-30.0$ to $30.0-60.0 \mathrm{~cm}$, then decreased to 0.17 and $0.11 \%$ with increasing the layer depth to $60.0-90.0$ and to $90.0-120.0 \mathrm{~cm}$, respectively.

Data of Fig. 6 ( $A$ and $\mathrm{B}$ ) illustrate a highly positive significant correlation between soil organic matter content and the distance from the sea, where the correlation coefficients are $0.84,0.91,0.74$ and 0.78 for layers $0.0-30.0,30.0-60.0,60.0-90.0$ and $90.0-120.0$,respectively. The correlation studied also reveal that the means of organic matter of profiles significantly and positively correlated with the distance from the sea $(R=$ 0.91).

Soil organic matter content tend to be high in the rest profiles (6-19), where it is amounted by $0.36 \%$ ( layers mean of profile 19 ) at the farthest point from the sea and $0.46 \%$ at the nearest point from the sea ( layers mean of profile 6 ). In most cases of profiles 6-19 soil organic matter contents were higher in surface layer then decreased with increasing the soil depth. The correlation studied also reveal that the means of organic matter of profiles significantly positive correlated with the distance from the sea as it is shown in Fig. (6) $(R=0.4)$. 
EL-Agrodi, M. W. M. et al.
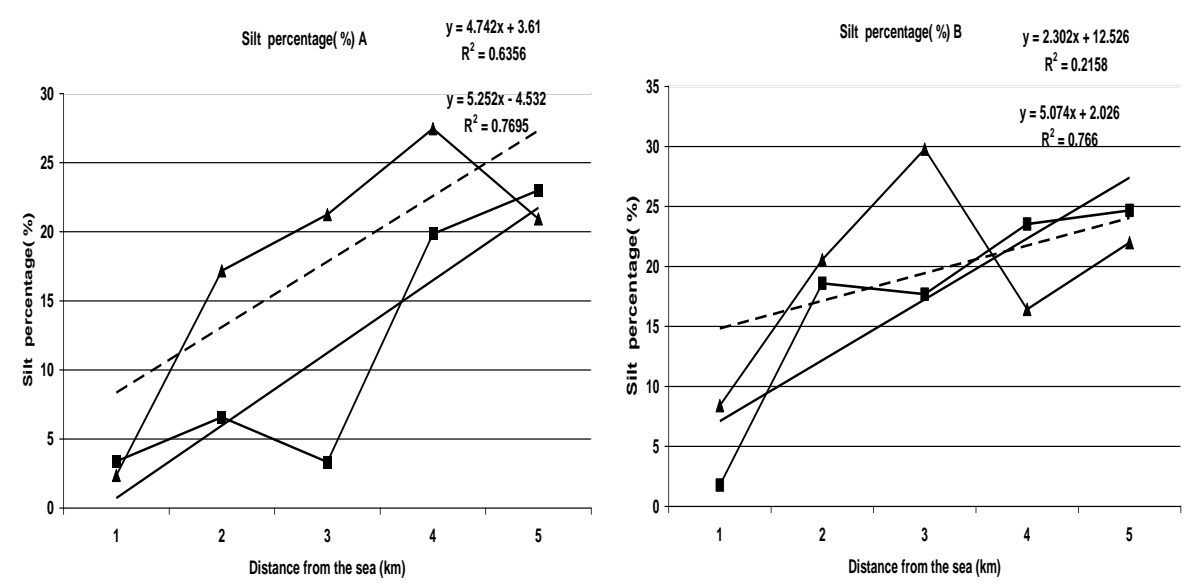

$\square 0-30 \rightarrow-30-60--\operatorname{Linear}(0-30)$ 一 Linear (30-60)

Silt percentagel $\%$ oc $C \quad y=0.6656 x+37.673$

$R^{2}=0.0894$

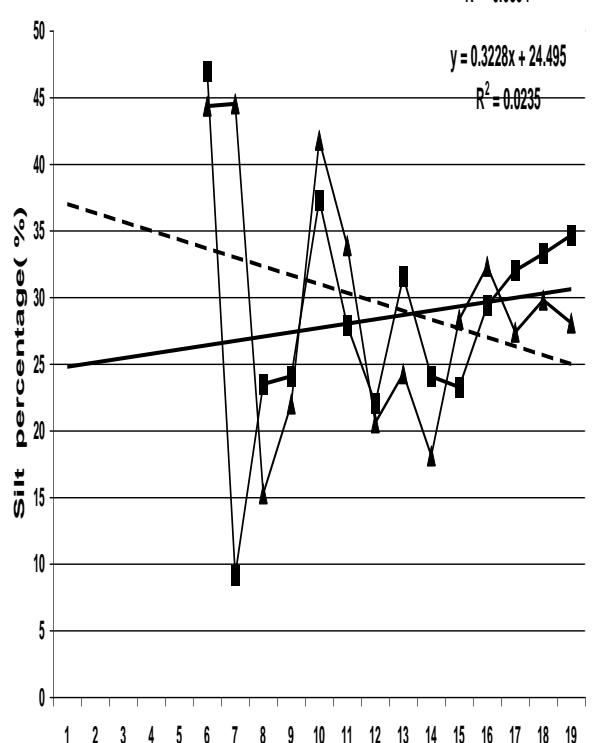

Distance from the sea $(\mathrm{km})$

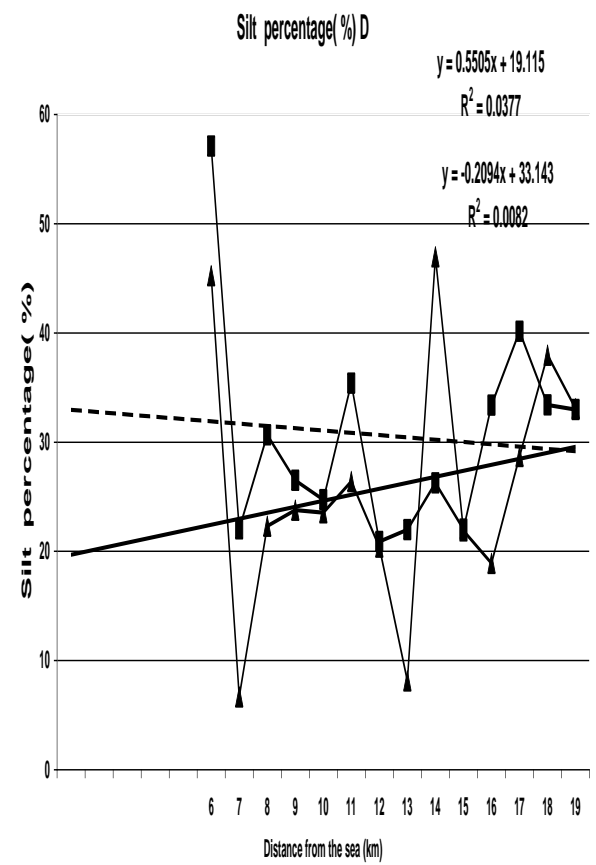

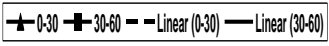

$+0090+\mathbf{0} 00120$ -

Fig.(4): Silt percentage of the studied soil layer in relation to the distance from the sea. ( $A=$ profiles from 1 to $5-0-30$ and $30-60$ $\mathrm{cm}$ depth, $B=$ profiles from1 to $5-60-90$ and $90-120 \mathrm{~cm}$ depth, $C=$ profiles from 6 to $19-0-30$ and $30-60 \mathrm{~cm}$ depth and $D=$ profiles from 6 to $19-60-90$ and $90-120 \mathrm{~cm}$ depth) 
Clay percentage $(\%)$ A

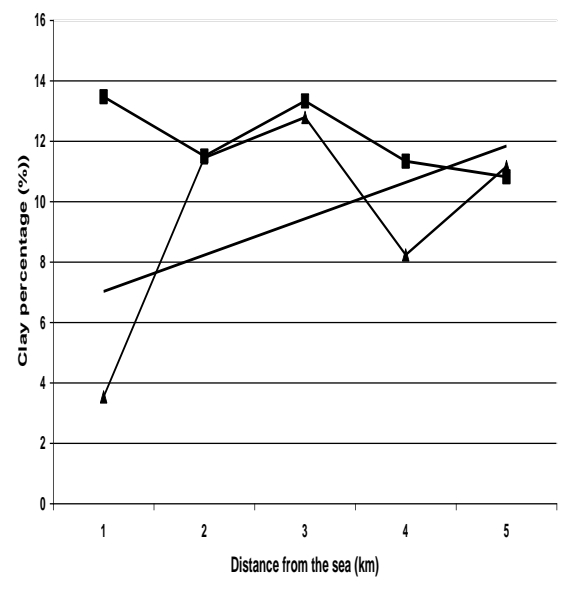

$+0.30 \div 30.60$ - Linear $(0.30)$

Clay percentage $(\%) \mathrm{C}$

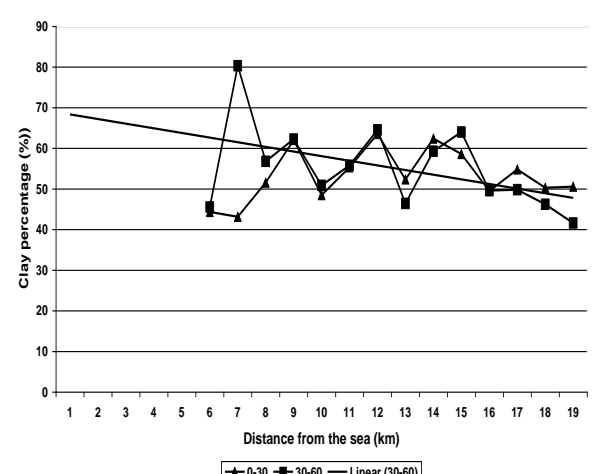

$\rightarrow 0.30-30-60$ - Linear $(30-60)$
Clay percentage $(\%)$ B

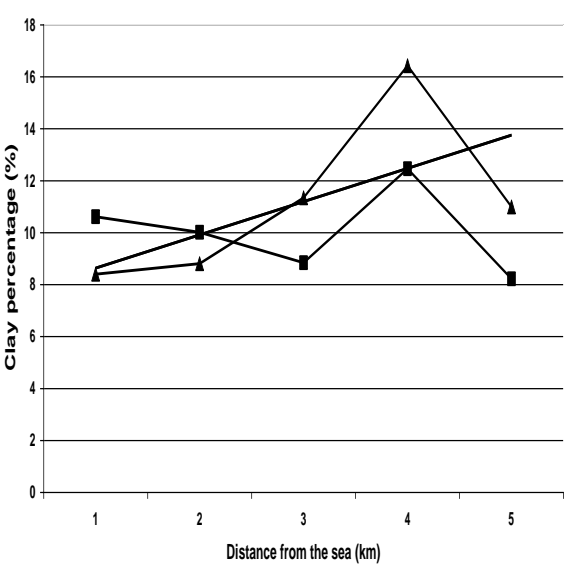

×60-90 - $90-120$ - Linear (60-90) — Linear (60-90)

Clay percentage $(\%) D$

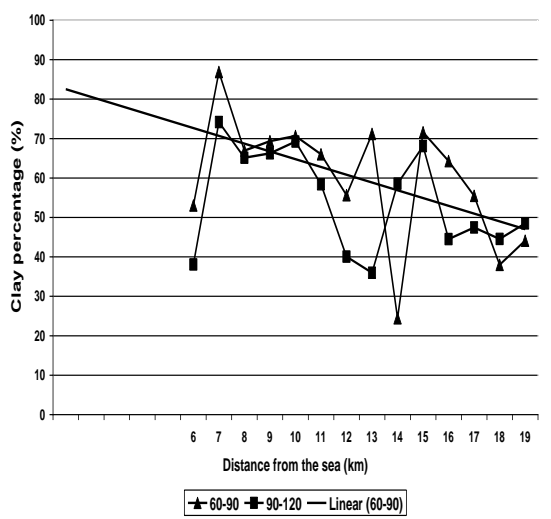

Fig. (5): Clay percentage of the studied soil layer in relation to the distance from the sea. $(A=$ profiles from 1 to $5-0-30$ and $30-60$ $\mathrm{cm}$ depth, $B=$ profiles from1 to $5-60-90$ and $90-120 \mathrm{~cm}$ depth, $\mathrm{C}=$ profiles from 6 to $19-0-30$ and $30-60 \mathrm{~cm}$ depth and $D=$ profiles from 6 to $19-60-90$ and $90-120 \mathrm{~cm}$ depth).

The highest organic matter content value $(0.86 \%)$ was found in profile 10 at the depth of $0-30 \mathrm{~cm}$, while the lowest value $(0.04 \%)$ was found in profile 2 at the depth of $90-120 \mathrm{~cm}$. These results may be attributed to organic fertilizers addition and soil management. These results are in agreement with the results of Hayn and Naidu (1998) who stated that additions of organic manures result in increasing soil organic matter content. The content of Dumyat soil under study from organic matter was lower and its content considered low than optimum. 


\section{Total carbonate content}

Data of Fig (7) show the total carbonate of the studied layers of profiles. In general, total carbonate percentage increased with increasing the distance from the Mediterranean Sea. Data indicates also that total carbonate content of the upper layers $0.0-30.0$ and $30.0-60.0 \mathrm{~cm}$ of first five profiles were very low, where it didn't increase than $0.73 \%$ (profile no 5 from $0.0-$ $30.0 \mathrm{~cm}$ layers). The lower layers of these profiles also have a lower content of total carbonate except of profile 4 . The total carbonate of layers $60.0-$ 90.0 and $90.0-120 \mathrm{~cm}$ are higher (3.0 and $2.2 \%$ ).

The total carbonate of the heavy textured soil (from $6-19$ ) as it is found in the previous Fig. 7 lie in the normal range of total carbonate of delta soil (1.42\% layers mean of profile 11 and 4.425 means of profile 14). Total carbonate distribution within each profile didn't have a stable trend, but in most cases the second layers have the highest amount of total carbonate compared with the upper or the lower layer. The linear correlation between total carbonate content and the distance from the sea is positive, but the increasing rate is very high in the first 5 profiles than that of the remains profile $(6-19)$. As it is shown in Fig. (7) and the concomitant linear equations. Dumyat soils under study content of total carbonate percentage were low and it considers a non calcareous soil, except at the depth of $30-60 \mathrm{~cm}$ in profiles number 14 and 16 .

\section{Saturation percentage}

Saturation percentage reflects the void distribution which affected by particle size distribution, in the same textured class soils with high salinity content they have a higher saturation percentage. The presence of expanded clay minerals to a large extent controls the saturation percentage value.

Data of Fig. (8) show the saturation percentage of studied soil. The first five profiles (light textured soil) exhibited a lower saturation percentage compared to the other profile (from 6 to 19) which classified as a heavy textured soil. Relatively, the obtained results of saturation percentage of soils nearest the sea are high (33.5 to $40.2 \%$ ) compared with the other soil lie in the same textured class. This may be due to dominance of very fine sand and silt in soil particles and to the higher soil salinity level. So, relatively higher values of saturation percentage of all studied profile layers (from 6 to 19) were found due to presence of expanding clay minerals such as montmorillonite. The montmorillonite percent ranges from $62.68 \%$ to $85.04 \%$ with an average of $73.42 \%$, and Kaolinite varies from $14.96 \%$ to $37.32 \%$ with an average of $26.43 \%$ in delta soils (Abd-Allah et al., 2009) .

In most cases, saturation percentage of the lower layers is higher than that of the upper layers. The contrast trend was found in profile 11 (saturation percentage of layer $C$ is the lowest values than that of the other layers), in profiles 12, 13 and 18 (saturation percentage of layer $D$ is the lowest values than that of the other layers), that caused by a slight coarse textured of this layer compared with the other layers. 

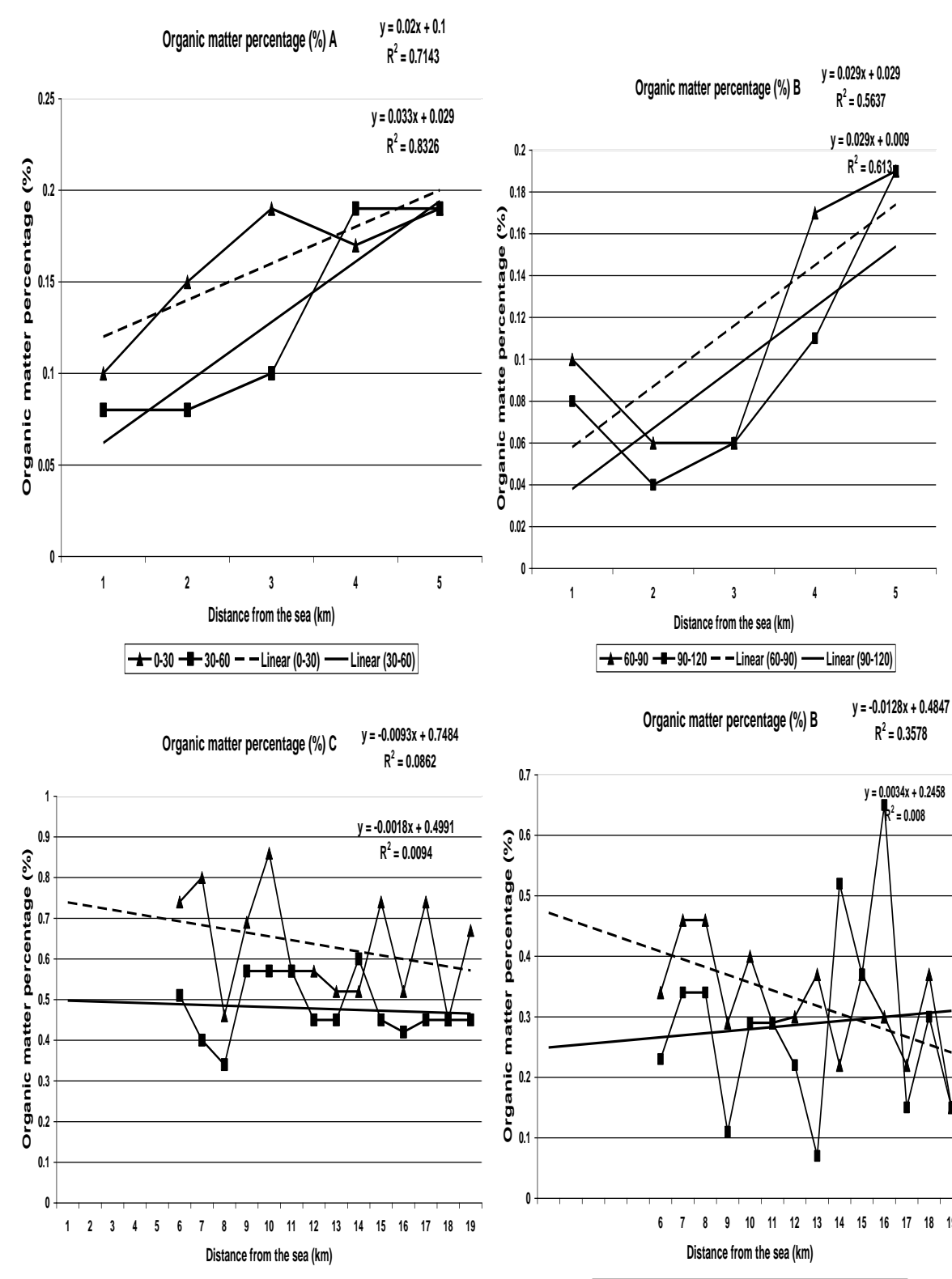

$\mp 0.30+-30.60--$ Linear $(0.30)$ - Linear $(30.60)$

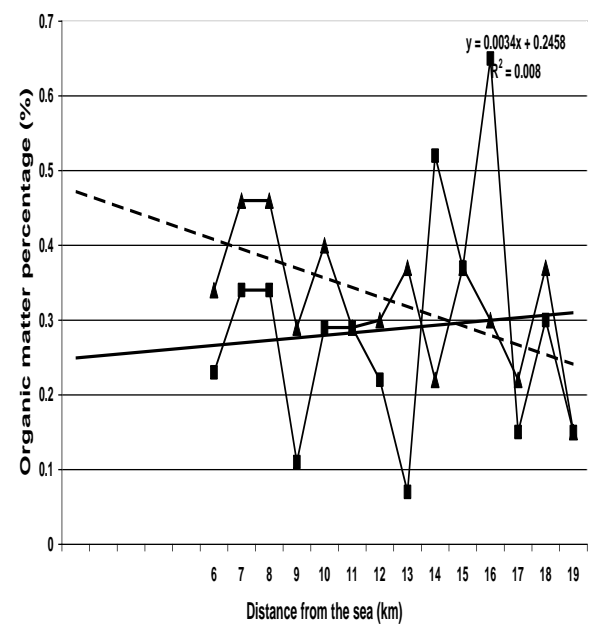

$+60.90+90-120$ - - Linear (60-90) —Linear (90-120)

Fig. (6): Soil organic matter percentage of the studied soil layer in relation to the distance from the sea. $(A=$ profiles from 1 to $5-$ 0-30 and 30-60 cm depth, $B=$ profiles from 1 to $5-60-90$ and 90-120 cm depth, $C=$ profiles from 6 to $19-0-30$ and $30-60 \mathrm{~cm}$ depth and $D=$ profiles from 6 to $19-60-90$ and $90-120 \mathrm{~cm}$ depth). 


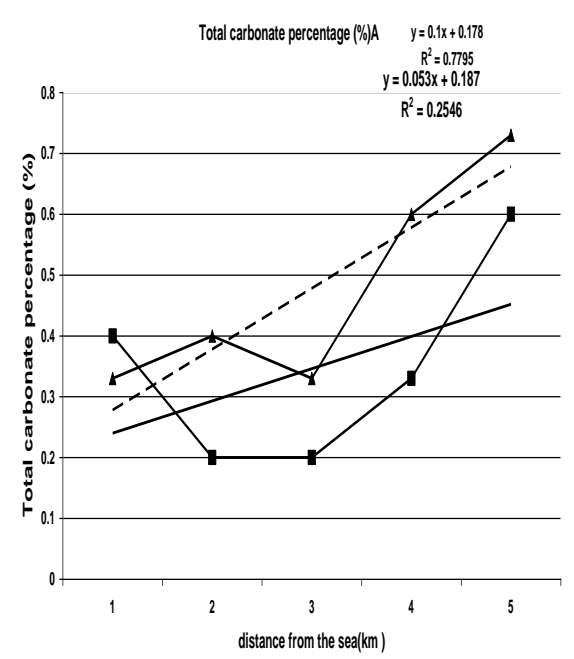

$+0.30+-30.60--$ Linear $(0.30)$ - Linear $(30.60)$

Total carbonate percentage $(\%) C$

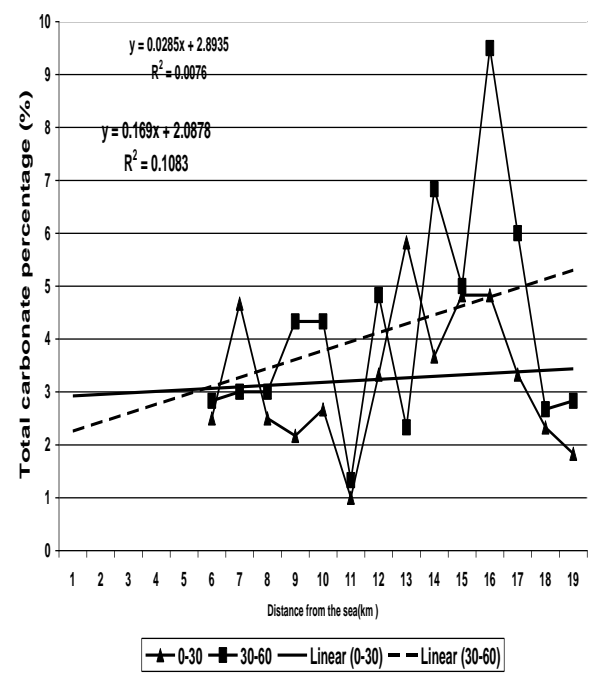

Total carbonate percentage $(\%) B \quad y=0.286 x-0.038$

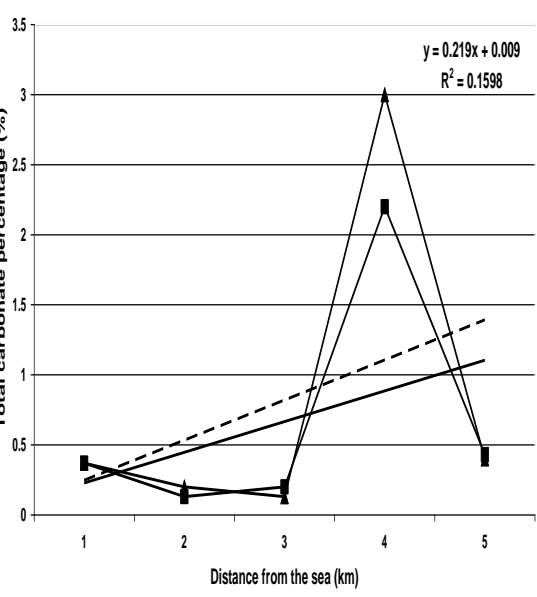

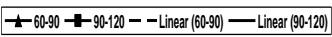

Total carbonate percentage $(\%)$ D $\quad y=0.0205 x+2.3762$

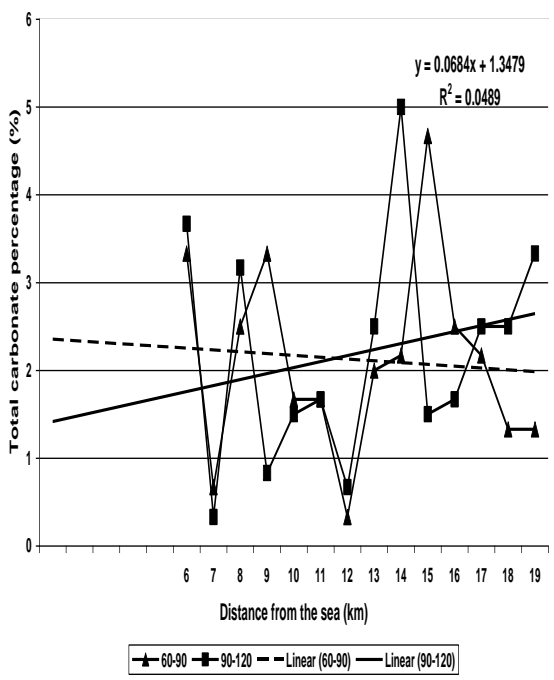

Fig. (7): Total carbonate percentage of the studied soil layer in relation to the distance from the sea. $(A=$ profiles from1 to $5-0-30$ and 30-60 cm depth, $B=$ profiles from1 to $5-60-90$ and $90-120 \mathrm{~cm}$ depth, $C=$ profiles from 6 to $19-0-30$ and $30-60 \mathrm{~cm}$ depth and $D$ $=$ profiles from 6 to $19-60-90$ and $90-120 \mathrm{~cm}$ depth). 

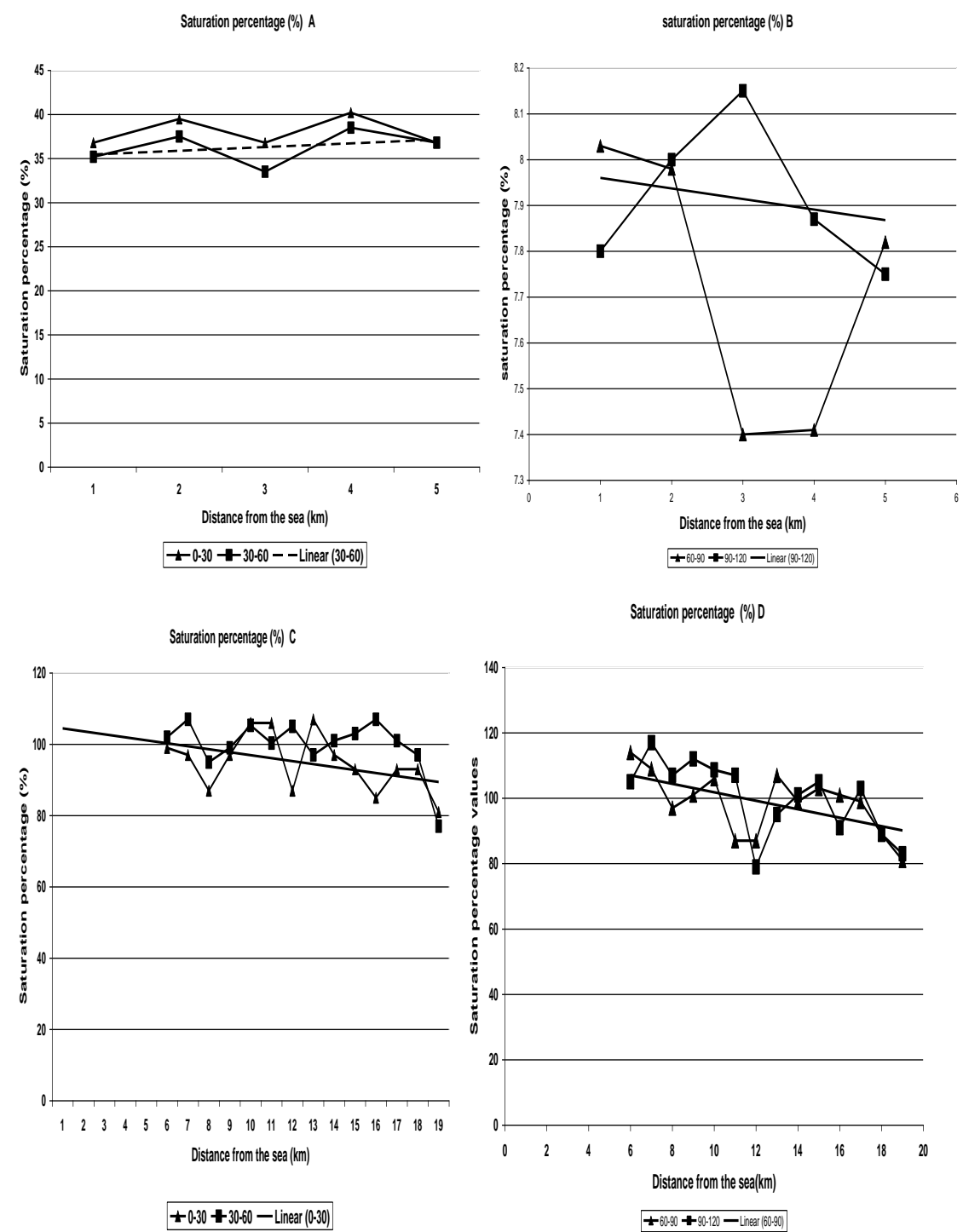

Fig. (8): Soil saturation percentage of the studied soil layer in relation to the distance from the sea. $(A=$ profiles from 1 to $5-0-30$ and 30-60 cm depth, $B=$ profiles from1 to $5-60-90$ and $90-120 \mathrm{~cm}$ depth, $C=$ profiles from 6 to $19-0-30$ and $30-60 \mathrm{~cm}$ depth and $D=$ profiles from 6 to $19-60-90$ and $90-120 \mathrm{~cm}$ depth).

Non significant correlation (0.039) between soil saturation percentage and the soil layer depth was noticed. These results may be due to soil clay content and sand which have a significant correlation between soil saturation percentage and clay content, soil saturation percentage and silt content, soil 
saturation percentage and fine sand and between soil saturation percentage and coarse sand were $0.912,0.47,-0.66$ and -0.52 , respectively.

\section{Soil reaction $(\mathrm{pH})$}

Data of Fig. (9) reveal the soil pH values along $19 \mathrm{~km}$ from the sea beach. In general the highest value of soil pH (8.4) was in the upper layer 0.0 $-30.0 \mathrm{~cm}$ (less than the critical level of alkaline soil 8.5) at $16 \mathrm{~km}$ from the sea beach. In layer $B, C$, and $D$ the highest values also were found at the same location $(8.85,8.65$, and 8.6 , respectively). The lowest values $(7.52,7.4$ and 7.7) were recorded at 11,3 and $10 \mathrm{~km}$ for layers $B, C$, and $D$, respectively. As it is shown in Fig. (9), the linear correlation between soil pH and the distance from the sea, soil $\mathrm{pH}$ of layer $\mathrm{A}$ and $\mathrm{B}$ was increased with increasing the distance from the sea in the two groups of profiles. Where $\mathrm{pH}$ of layers $\mathrm{C}$ and $D$ was decrease with increasing distance in the first group of profiles (1$5)$ then increased with increasing distance in the second group (profiles 6 19).

No constant trend was found between soil $\mathrm{pH}$ and soil depth where, soil pH in profiles 2, 8, 9, 12, 14, 15 and 19 tends to increase with soil depth. Soil $\mathrm{pH}$ in profiles $1,3,6,7$, and 16 tends to increase with soil depth up to 60 $\mathrm{cm}$, on the other hand soil $\mathrm{pH}$ of profiles $4,5,10,11,13$ and 18 tended to decrease up to $60 \mathrm{~cm}$. These results may be regarded to its content of organic matter and total carbonate which is correlated with soil reaction $(\mathrm{pH})$ by 0.12 and 0.41 , respectively.

A

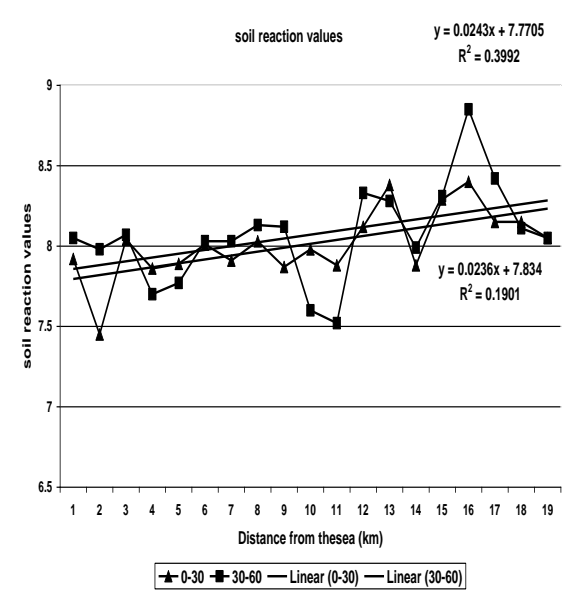

B

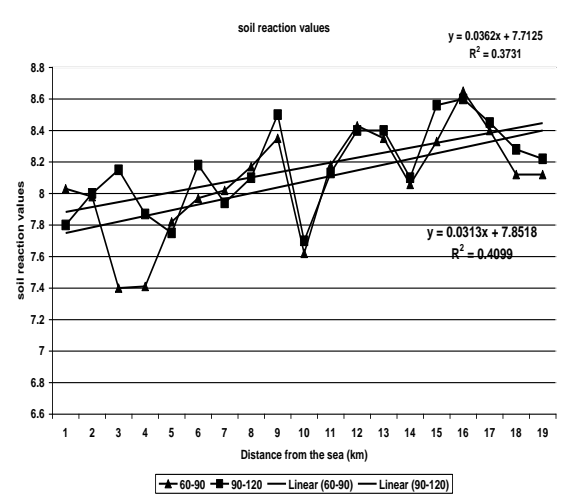

Fig. (9): Soil pH of the studied soil layer in relation to the distance from the sea. $(A=$ profiles from 1 to $19-0-30$ and $30-60 \mathrm{~cm}$ depth, $B=$ profiles from1 to $19-60-90$ and $90-120 \mathrm{~cm}$ depth.

\section{Cation Exchange Capacities of the studied soils}

As it is shown in Fig.10 the cation exchange capacities of the studied soil profiles were varied from $3.38 \mathrm{cmol} / \mathrm{kg}$ to $67.56 \mathrm{cmol} / \mathrm{kg}$. The lowest values were $3.38,12.59,10.19,11.56$ and $12.3 \mathrm{cmol} / \mathrm{kg}$ for the first, 
second, third, fourth and fifth profile, which was loamy sand or sandy loam in texture. The heavy textured soil (silty clay to clay) from profile 6 to profile 19 have a CEC values ranged between $33.88 \mathrm{cmol} / \mathrm{kg}$ for profile 19 and 67.56 $\mathrm{cmol} / \mathrm{kg}$ for profile 18 .

Layer C of profile 10 and 16 have the highest values of cation exchange capacity $(60.75$ and $95 \mathrm{cmol} / \mathrm{kg})$. This is concomitant with the highest clay content of these layers (70.62 and $64.27 \%$ ) in spite of lower organic matter content of these layers (0.4 and $0.3 \%)$. The relation between cation exchange capacity of the studied soil and its clay content (Fig. 11) was explained by the following equation $y=0.9984 x+8.7467$.

As it is shown in Fig.10 (C and D ) in all studied profiles, cation exchange capacity of $B$ layer is higher or equal to that of $A$ layer except in profile 7 where the cation exchange capacity value of layer A and B were 42.5 and $38.75 \mathrm{cmol} / \mathrm{kg}$. This trend is acceptable, where the fine particle migration was happened. In profiles $3,6,7,8,9,10,11,14,15$ and 16 the cation exchange capacity of $C$ layer are higher than that of $A$ and $B$ layers due to high clay content of this layer than A and B layer (clay content exceeds than two fold of silt , the mains two components with active surface area in soil). In profiles 3 and 14 silt is the dominant component.

Regarding to the effect of the distance from the sea, Fig.10 reveals that cation exchange capacity of each layer increased with increasing the distance from the sea. The correlation coefficients for A, B, C, and D layer of cation exchange capacity and the distance from the sea are $0.72,0.73,0.65$ and 0.42 .

Sharp increase or decrease was noticed with increasing the distance from the sea in each soil layer and lower correlation coefficient values declare the absence of the sea effect on that trait (Fig.10), hence the agriculture practices effects play the dominant role in these changes.

These results may reflect the percentage of sand and clay in this soil, where, the correlations between the cation exchange capacity and coarse sand $(-0.77)$, cations exchange capacity and fine sand $(-0.80)$, cation exchange capacity and silt percentage $(0.42)$ and cation exchange capacity and clay (0.78) were observed. These results are in agreement with that of Tayel, et al. (2010) who stated that increase and decrease of cation exchange capacity values is closely correlated to the clay content from one side and from the other one the lowest effects of $\mathrm{CaCO}_{3}$ and organic matter and Drake and motto (1982) which, their results show that, greater than $50 \%$ of the variation in CEC could be explained by the variation in clay and organic carbon content for several soil types in New Jersey. 
EL-Agrodi, M. W. M. et al.
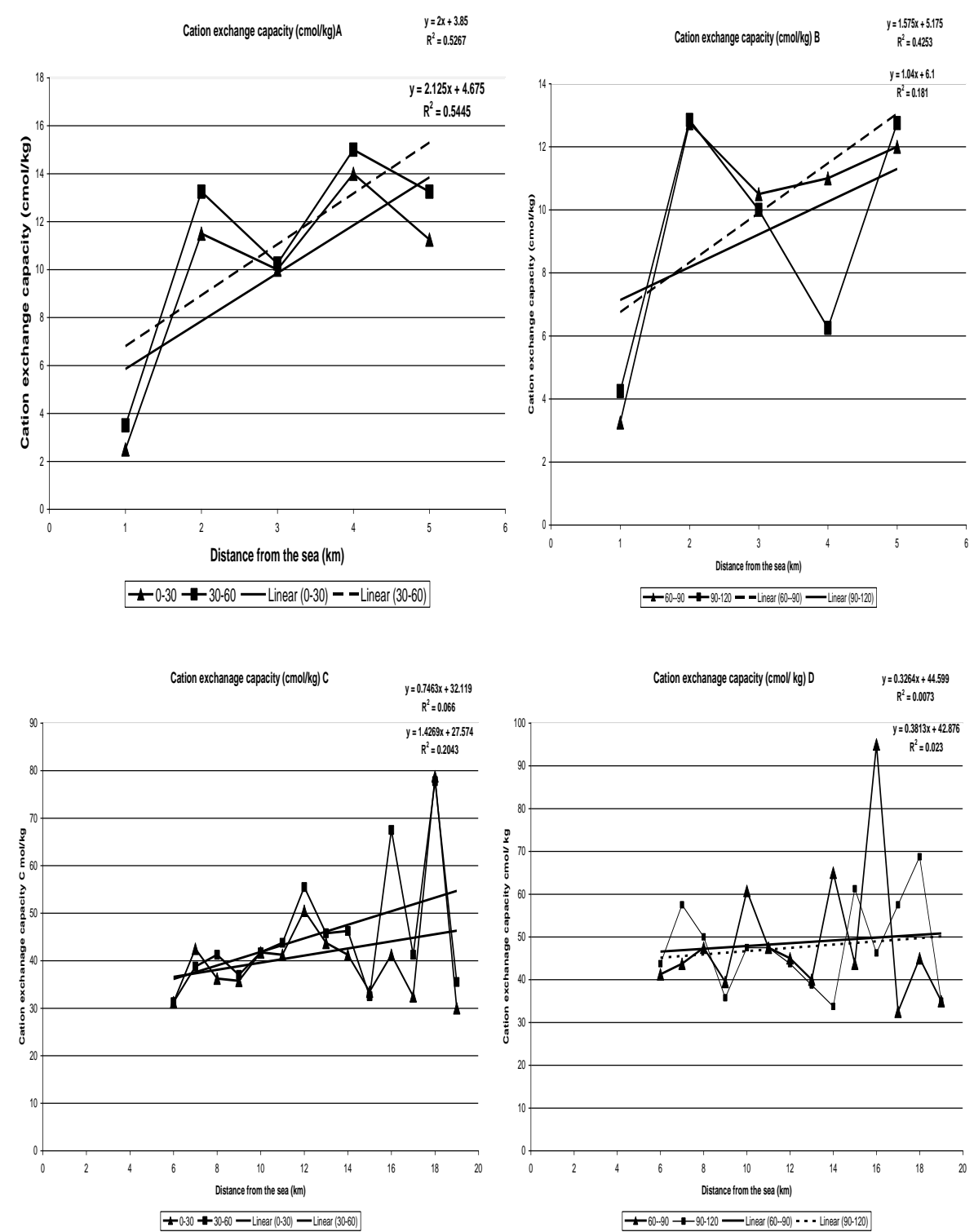

Fig. (10): Cation exchange capacity of the studied soil layer in relation to the distance from the sea. $(A=$ profiles from1 to $5-0-30$ and $30-60 \mathrm{~cm}$ depth, $B=$ profiles from 1 to $5-60-90$ and $90-$ $120 \mathrm{~cm}$ depth, $\mathrm{C}=$ profiles from 6 to $19-0-30$ and $30-60 \mathrm{~cm}$ depth and $D=$ profiles from 6 to $19-60-90$ and $90-120 \mathrm{~cm}$ depth) 


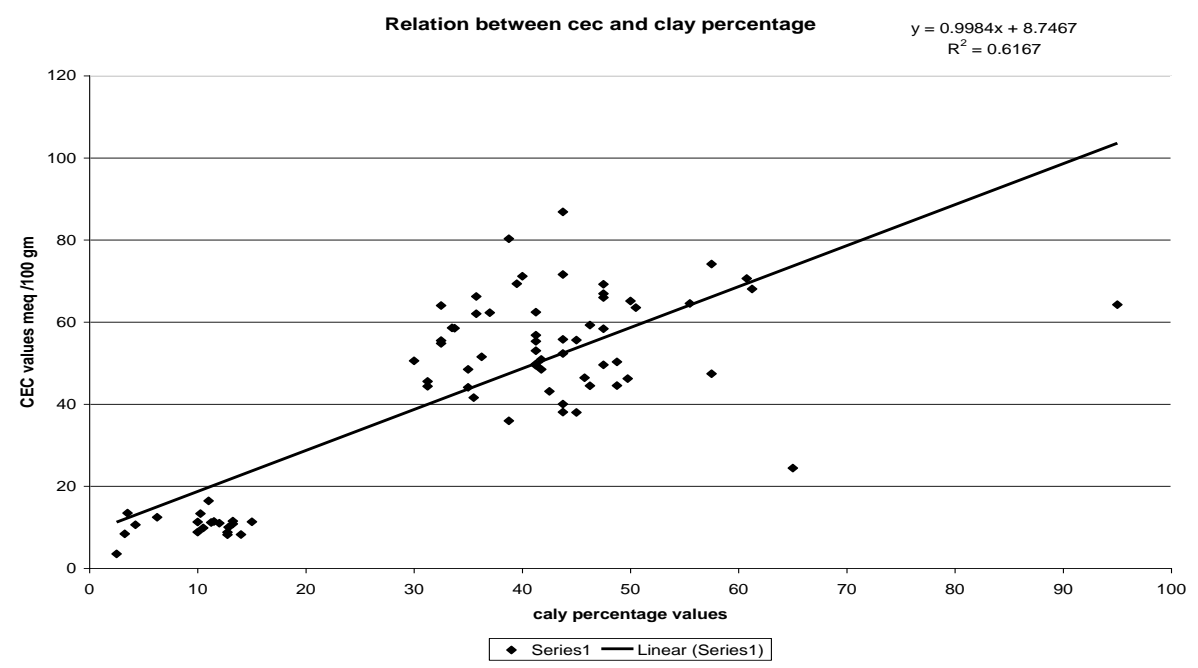

Fig. (11): The relation between cation exchange capacity of the studied soil and its clay content.

\section{Exchangeable sodium percentage (ESP \%)}

Data of Fig. 12 (A, B, C and D) reveal the exchangeable sodium percentage of the studied soils. The exchangeable sodium percentage of the studied soil layers (profile 1 to 5 ) ranging between $0.99 \%$ (layer D of profile 1) to $15.84 \%$ (layer $A$ of profile 1). Exchangeable sodium percentage of profile 1 layer $A$, only exhibited sodicity feature in this trait, where its value was above the threshold level (15\%). No constant trend was found in exchangeable sodium percentage with increasing the distance from the sea up to $5 \mathrm{~km}$ in $A, B$, and $C$ layers, where in layer $D$ exchangeable sodium percentage increased with increasing the distance up to $4 \mathrm{~km}$ then decreased. This decrease may be due to the presence of drain lines.

Profiles from 6 to 10 have a higher exchangeable sodium percentage values in soil layers. The exchangeable sodium percentage values of layer $B$ of profile 6, 7 and 10are the highest within each profile, 56.94, 34.37 and $18.79 \%$, respectively. The highest values of exchangeable sodium percentage in profile 8 and 9 were found in layer $A$ and $D(43.55 \%$ for profile 8 layer $A$ and $57.66 \%$ for profile 9 layer D). The exchangeable sodium percentage profile means of these profiles (6-9) are 44.94, 21.06, 33.78 and $36.5 \%$, respectively. This increase in exchangeable sodium percentage didn't accompanied with organic matter and fine particle fractions of soil. A non significant correlation between ESP \% and the soil depth (0.131) was found.

The exchangeable sodium percentage profiles means of profiles 11 , $12,13,14,15,16,17,18$ and 19 are $15.20,10.38,19.77,16.60,10.73$, $10.10,10.17,5.66$ and $5.16 \%$ respectively. In Domyat soils under study, adding gypsum is required (profiles from 6-14) to reduce ESP below 15\% hence improve most of soil properties. 
EL-Agrodi, M. W. M. et al.

Exchangable sodium percentage (ESP\%)

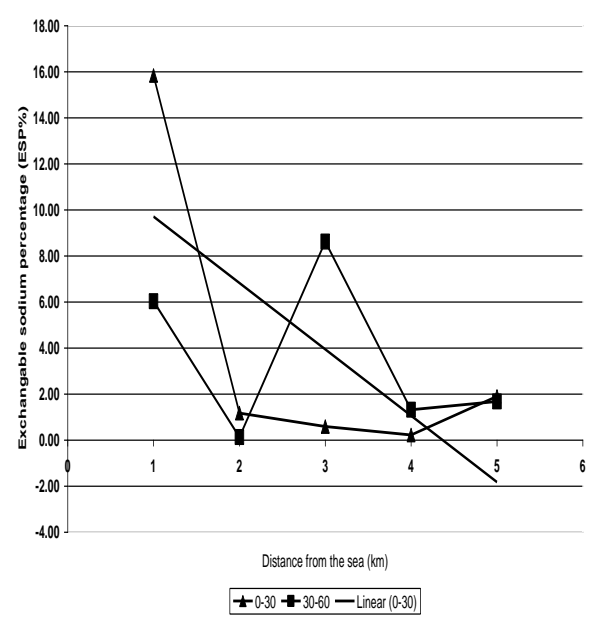

Exchangable sodium percentage (ESP\%)

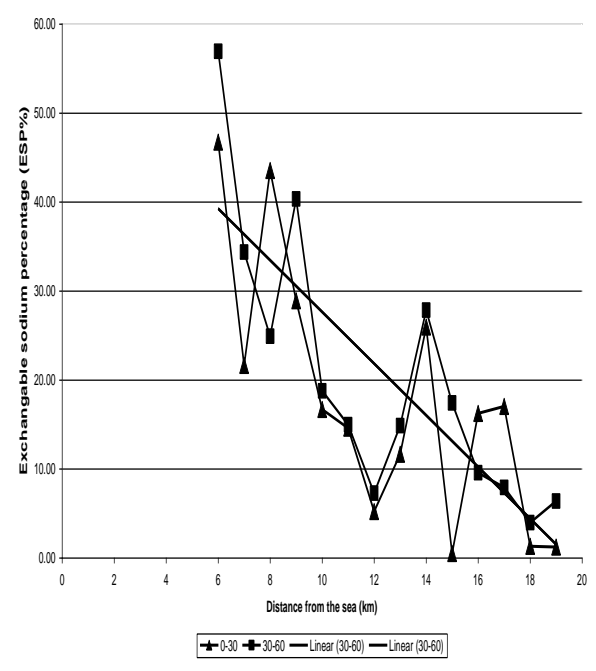

Exchangable sodium percentage (ESP\%)

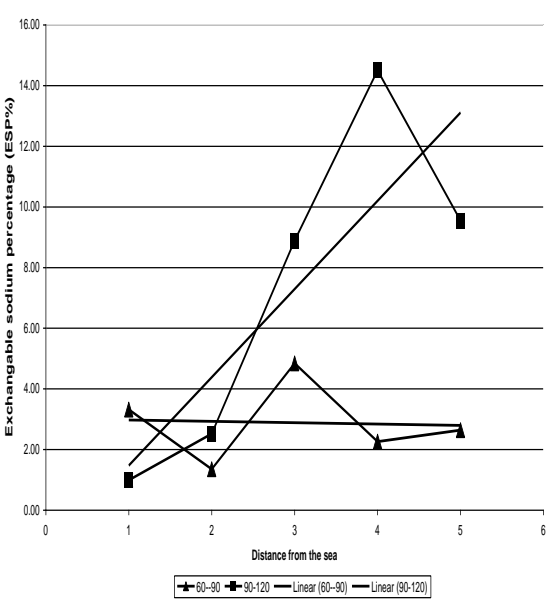

Exchangable sodium percentage $[$ ESPYG 0

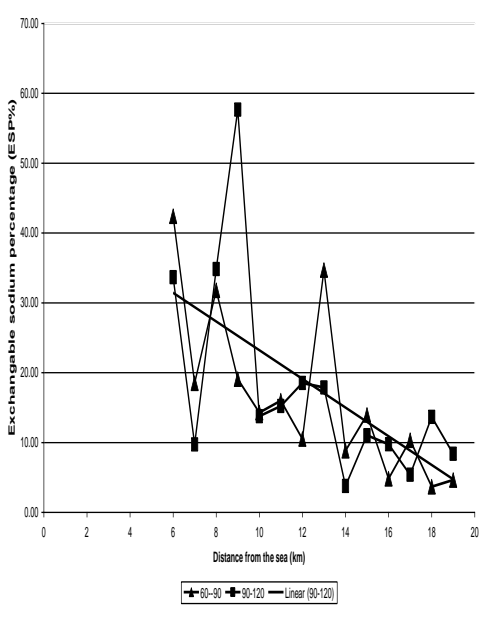

Fig. (12): Exchangeable sodium percentage of the studied soil layer in relation to the distance from the sea. $(A=$ profiles from1 to 5 0-30 and $30-60 \mathrm{~cm}$ depth, $B=$ profiles from1 to $5-60-90$ and 90-120 cm depth, $C=$ profiles from 6 to $19-0-30$ and $30-60 \mathrm{~cm}$ depth and $D=$ profiles from 6 to $19-60-90$ and $90-120 \mathrm{~cm}$ depth). 


\section{REFERENCES}

Abd-Allah; A. M.; Dawood, Y. H. ; Awad, S. A. and W. A. Agila (2009). Mineralogical and Chemical Compositions of Shallow Marine Clays, East of Cairo, Egypt: A Geotechnical Perception. Earth Sci., 20 (1), 141-166.

Black, C. A. (1965)." Methods of soil and water analysis". Part 2 : Madison, Wisconsin, USA.

Costat Version 6.303, copyright, (1998-2004) CoHort software 798 lighthouses Ave. PMB320. Monterey CA, 93940, USA.

Dewis, J. and F. Freitas, (1970). "Physical and Chemical Methods of Soil and Water Analysis". FAO, Rome, pp: 275.

Drake,E. H. and H. L. motto (1982). Analysis of the effect of clay and organic matter content on the cation exchange capacity of Soil. Sci., 133: 281-288.

Hayn, R.J. and R. Naidu (1998) Influence of lime, fertilizer and manure applications on soil organic matter content and soil physical conditions: a review.Nutrient Cycling in Agroecosystems 51: 123-137

Jackson, M. T. (1967)." Soil chemical analysis," Constable Co.Ltd. London .

Tayel, m. Y ; Abd El- Hady, m. and E.I. Eldardiry (2010) soil structure affected by some soil characteristics. American -Eurasian J. Agri. and Environ Sci.7 (6): $705-712$

$$
\begin{aligned}
& \text { تأثير البعد عن البحر المتوسط علي بعض خواص أراضي محافظة دمياط. }
\end{aligned}
$$

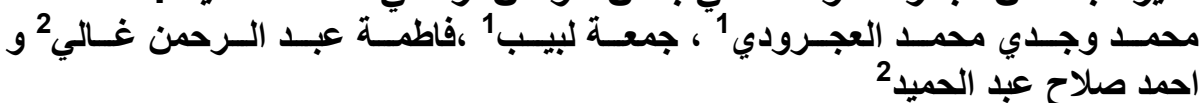

$$
\begin{aligned}
& 1 \text { قسم الأراضي ـ كلية الزبلة الزراعة - جامعة المنصورة } \\
& 2 \text { قسم الأراضي ـ كلية الزراعة بلمياط - جامعة المنصورة }
\end{aligned}
$$

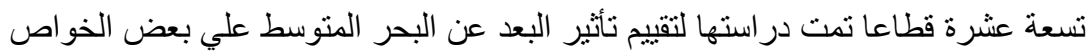

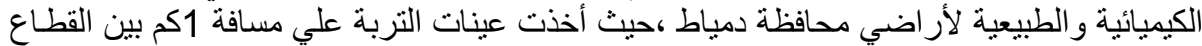

$$
\begin{aligned}
& \text { و الأخر و أربعة طبقات لكل قطاع (صفر- } 30 \text { و 30-60 و } 60 \text { - } 90 \text { و } 90 \text {-120 سم ) وقدان } \\
& \text { اخذت تلك القطاعات عموديا علي الساحل. }
\end{aligned}
$$

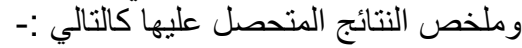

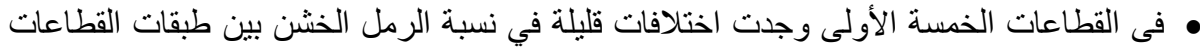

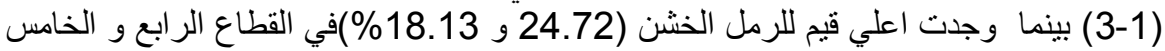

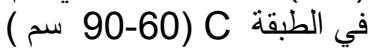

$$
\begin{aligned}
& \text { • النسبة المئوية للرمل الخشن في القطاعات من 6-19 كانت منخفضة جدا حيث لم تزد عن } 2.65
\end{aligned}
$$

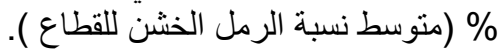

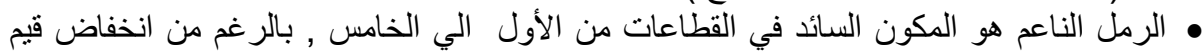

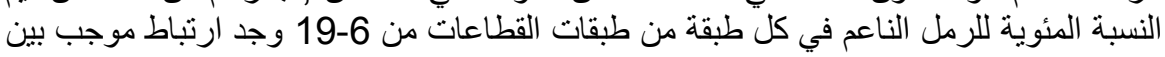

$$
\begin{aligned}
& \text { نسبة الرمل الناعم والبعد عن البحر المتوسط فئة وكان قيمة معامل الارتباط كالتالي: } 0.7 \text { و } 0.63 \\
& \text { و0.63 و } 0.41 \text { و } \\
& \text { • ازدادت نسبة السلت مع زيادة المسافة من البحر حتي وصلت الي } 22.65 \text { \% في القطاع رقم } 5
\end{aligned}
$$


EL-Agrodi, M. W. M. et al.

• محتوي القطاعات من 6-19 من السلت يقع بين 20.61 و 48.42 \% حيث وجدت أعلي قيمة اللسلت في القطاع رقم 6.

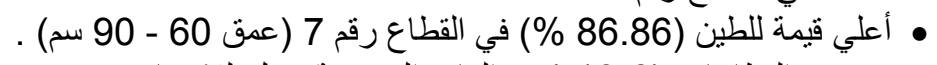
• محتوي القطاعات (6-19 )من المادة العضوية يميل للارتفاع حيث تقاعر نسبة المادة العضوية

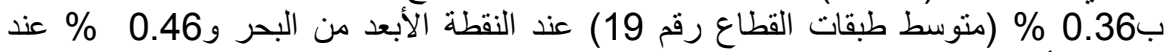

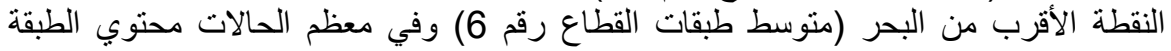

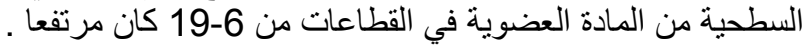

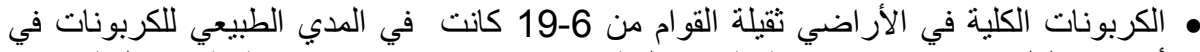

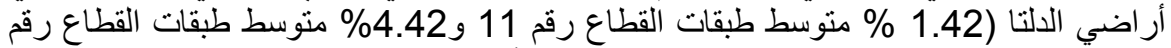

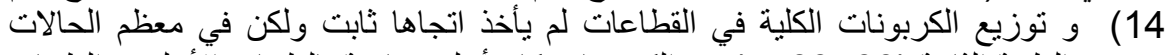
محتوي الطبقة الثانية (30 -60 سم) من الكربونات كان الكان أعلي مقارنة بالطبقات الأعلي و الطبقات الأعمق الإن

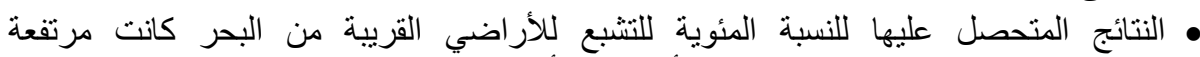

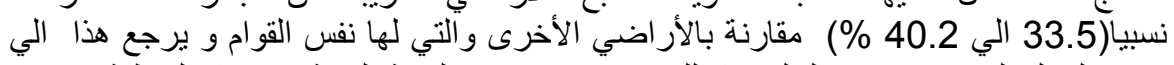

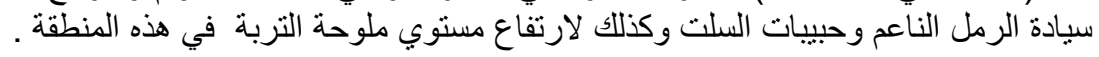

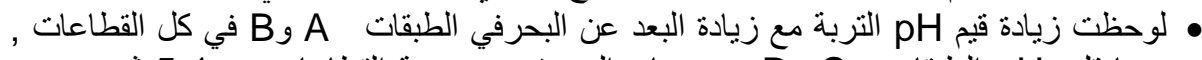

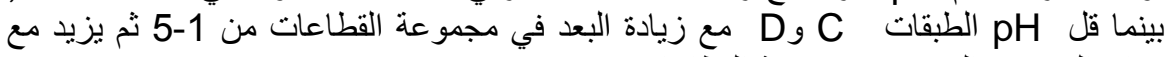

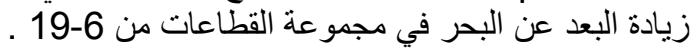
ه العلاقة بين السعة التبادلية الكاتيونية للأر اضي الدئ مندروسة ومحتو اها من الطين تتضح من خلال

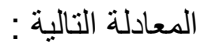
• 8.7467 + السعة التبادلية الكاتونية =

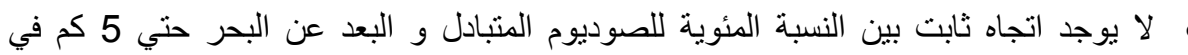

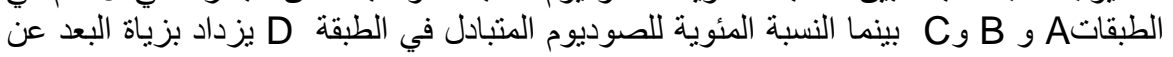

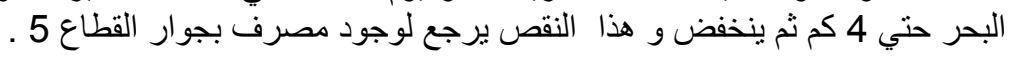

كلية الزراعة - جامعة المنصورة كلية الزراعة - جامعة الزقازيق جامعة المنورة أ.د / نبيه عطيه عطيه السيد أحمد الهد 